\begin{tabular}{c|c|c}
\hline \hline $\begin{array}{c}\text { Vol. 35(1):63-68 } \\
\text { http://dx.doi.org/10.4217/OPR.2013.35.1.063 }\end{array}$ & Ocean and Polar Research & March 2013 \\
\hline
\end{tabular}

\title{
Note
}

\section{Predicting the Invasion Pathway of Balanus perforatus in Korean Seawaters}

\author{
Keun-Hyung Choi ${ }^{1 *}$, Hyun-Woo Choi ${ }^{2}$, Il-Hoi Kim ${ }^{3}$, and Jae-Sang Hong ${ }^{4}$ \\ ${ }^{1}$ Ballast Water Center, KIOST \\ ${ }^{2}$ Oceanographic Data \& Information Center, KIOST \\ Ansan 426-744, Korea \\ ${ }^{3}$ Department of Biology, College of Natural Sciences, Gangneung-Wonju National University \\ Gangneung 210-702, Korea \\ ${ }^{4}$ Department of Ocean Sciences, College of Natural Sciences, Inha University \\ Incheon 402-751, Korea
}

\begin{abstract}
The European Common Barnacle Balanus perforatus Brugiére (Crustacea, Cirripedia) has been introduced into the east coast of Korea, presumably via the ballast water of ships. The species has since been spreading along both the northern and southern coast to the east, most likely due to alongshore currents. We predicted the potential range expansion of Balanus perforatus in Korean waters using Genetic Algorithm for Rule-set Prediction (GARP), an environmental niche modeling technique. The results show that much of the southern coastal waters of Korea could be colonized by the spread of the nonindigenous species, but that the west coast is unlikely to be invaded. More sampling on the west coast would enhance the predictability of the model. To our knowledge, this is the first report of its kind for predicting marine nonindigenous species in Korean waters using GARP modeling.
\end{abstract}

Key words : marine bioinvasion, habitat niche modelling, GARP, European barnacles

\section{Introduction}

Marine biological invasions constitute one of the greatest threats to biological diversity of the ocean, imperiling threatened and endangered species. It also alters the structure and ecological functioning of critical habitats, and affects aquaculture and fisheries, putting significant socio-economic stress on local fishing communities, often resulting in significant economic losses.

Korean seawaters and adjacent areas are known to be less invaded ecosystems than many, probably due to the relatively low volume of foreign waters being discharged (e.g., via ships ballast water (Ohtsuka et al. 2004). Nonetheless, surveys made in these waters show that some NIS have invaded the regions (Chavanich et al. 2010).

\footnotetext{
*Corresponding author. E-mail : keunhchoi@kiost.ac
}

One such recently invaded marine species is the barnacle Balanus perforatus Brugiére, 1789 (Crustacea, Cirripedia) from the European waters that has recently been discovered on the east coast of Korea. Monitoring shows that this species is spreading along the southern and northern coasts to the east (Kim and Hong 2010). Therefore, it is important to develop tools to predict which areas that have not been invaded are susceptible to the spreading of this species.

Ecological niche modeling can be a powerful tool for assessing the likelihood of nonindigenous species becoming established in an area, and has been widely used to predict areas of potential invasion by aquatic species (Stockwell and Peters 1999a; Iguchi et al. 2004; Herborg et al. 2007; Loo et al. 2007). To address the potential range of expansion of B. perforatus in Korean waters, we examined the performance of an environmental niche modeling 


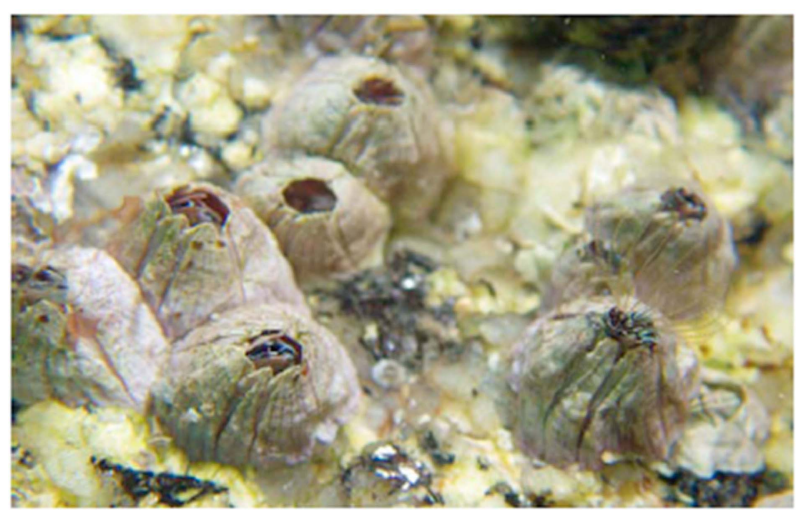

Fig. 1. The European barnacle, B. perforatus. The picture was taken from a rocky shore at Gampo on the east coast of Korea

technique in predicting whether coastal waters of Korean waters could be colonized by the spread of the nonindigenous species. To our knowledge, this is the first report of its kind for predicting marine invasive species in Korean waters using a habitat niche modeling.

B. perforatus is a large barnacle which grows to $30 \mathrm{~mm}$ in both diameter and height (Fig. 1). It is a warm water species between $36^{\circ} \mathrm{N}$ and $52^{\circ} \mathrm{N}$, occurring commonly in the Mediterranean and along the eastern Atlantic coast from North Wales to West Africa. Usually, it occurs in the lower half of the littoral zone, extending into the sublittoral on rocks and artificial structures, and is sometimes common in wave exposed situations. It has been expanding its range with the temperature increases which have occurred in recent decades (Herbert et al. 2003). It is found on rocks and man-made structures from the mid-shore to the neritic zone, and also forms part of the fouling community on the hulls of ships (Marine Life Information, $\mathrm{http}: / /$ www.marlin.ac.uk/speciesinformation.php?speciesID= 2719).

B. perforatus was identified in Korean waters for the first time in Guryongpo $\left(35^{\circ} 59^{\prime} 10^{\prime \prime} \mathrm{N}, 129^{\circ} 33^{\prime} 20^{\prime \prime} \mathrm{E}\right)$, Yangpo $\left(35^{\circ} 52^{\prime} 40^{\prime \prime} \mathrm{N}, 129^{\circ} 31^{\prime} 30^{\prime \prime} \mathrm{E}\right)$, and Gampo (35 $43^{\prime} 18^{\prime \prime} \mathrm{N}$, $129^{\circ} 30^{\prime} 27^{\prime \prime} \mathrm{E}$ ) Ports on June 24, 2006 (Kim and Hong 2010). Two years later, 31 sites were around South Korean coasts were sampled, and the results showed that 13 further sites were invaded by the species, and they were mostly concentrated on the east coasts where some of the important international shipping traffic ports such as Busan and Ulsan are located. B. perforatus has traversed a historic oceanographical distance, from the European waters to the Northwest Pacific waters. Therefore, it is possible to assume that the observed invasion pattern may suggest ships' hull fouling and/or their ballast water as pathways for the establishment of B. perforatus in Korean waters.

\section{Materials and methods}

We used Genetic Algorithm for Rule Set Production (GARP) (Stockwell and Peterson 1999b), an ecological niche modeling technique, to forecast the regions in Korean waters which are more susceptible to establishment by $B$. perforatus. Correlations between known species occurrences and a suite of environmental parameters were used to develop a series of decision rules that best summarize the niche dimensions of the species. We then projected these niche dimensions onto the environmental conditions of the Korean waters.

Geographically-referenced occurrence records were obtained for the range of introduction to Korean waters for the species. The occurrence data were collected from the surveys around the coastal waters of Korea which were made between 2006 and 2008 (Fig. 2). We selected environmental predictor variables that could be limiting for their habitat range of this inter-tidal fouling organism. We obtained all environmental data for Korean waters from the metadata available at the Korea Hydrographic Oceanographic Administration (http://www.khoa.go.kr/). Eight environmental parameters were used, including maximum and minimum values of sea surface temperature, salinity, suspended solids, and Chlorophyll a (all of the 5 years between 2008-2012). Five-year average values for

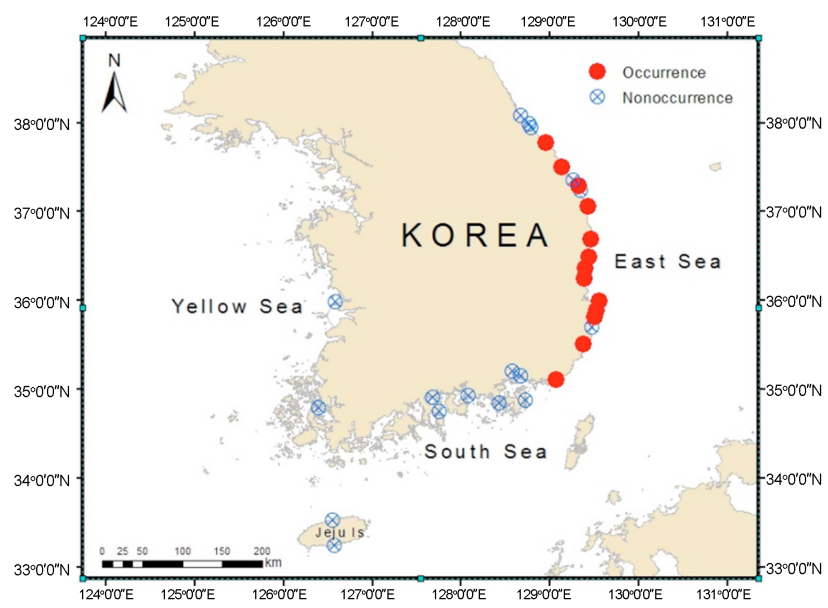

Fig. 2. Distribution map of the European barnacle, $B$. perforatus in Korean waters, with monitoring sites. Filled circles - identified during the survey in 2006 and 2008, empty circles - not identified during the survey 

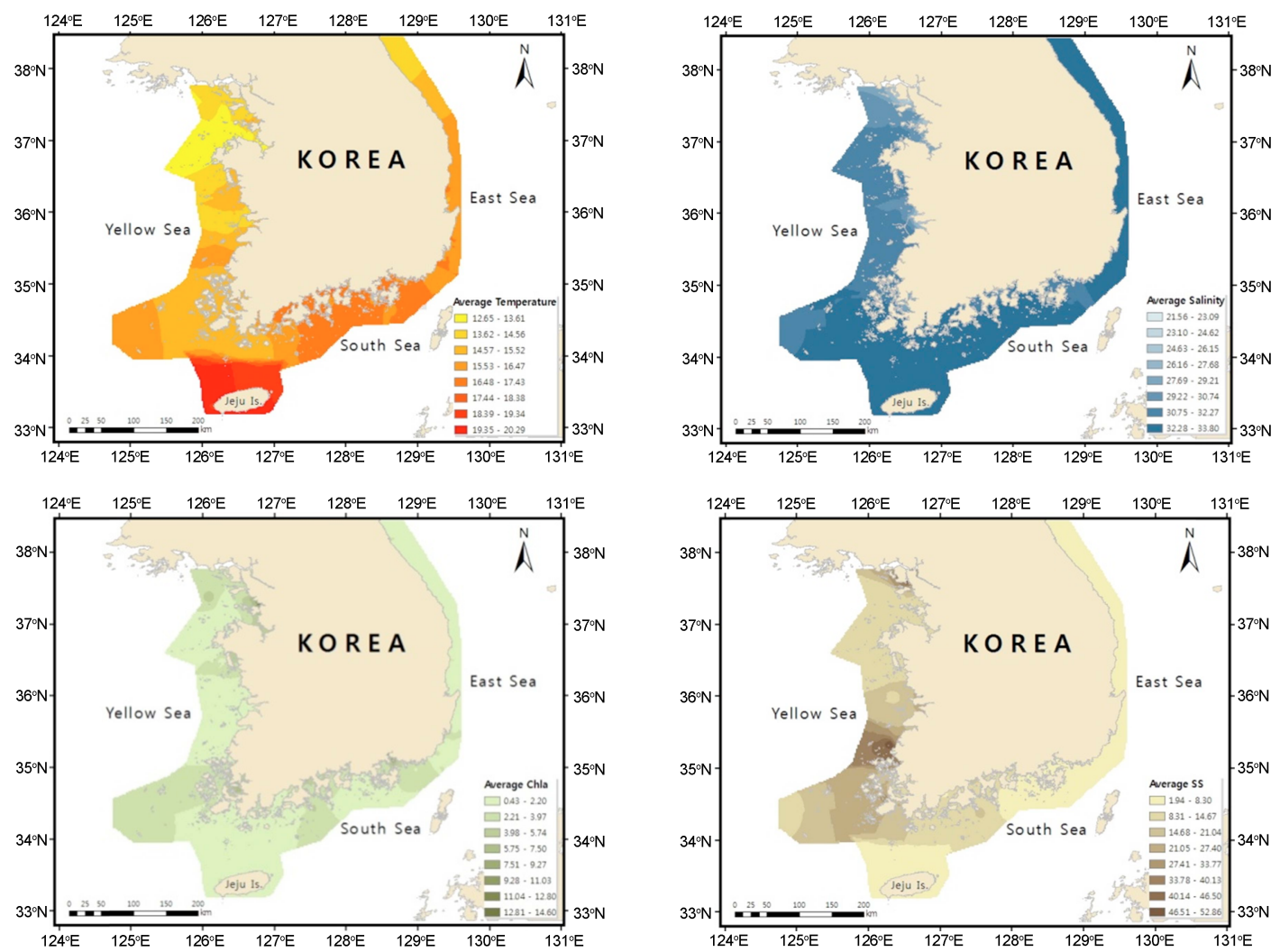

Fig. 3. Five year (2008-2012) average of environmental conditions. Top-left : temperature $\left({ }^{\circ} \mathrm{C}\right)$, Top right - salinity, bottom left - Chlorophyll a $\left(\mu \mathrm{g}^{-1}\right)$, bottom right - suspended solids (ppm)

environmental parameters of Korean coastal waters are shown in Fig. 3.

We built ecological niche models based on species occurrence and environmental data using Desktop GARP version 1.1.6 developed by R. Scachetti-Pereira for The University of Kansas Biodiversity Research Center in collaboration with the Reference Center for Environmental Information in Campinas, Brazil. We set the program for 20 runs, each with a convergence limit of 0.01 and a maximum of 1000 iterations to convergence. The program used all four built-in rule types and all their combinations to build the model: Atomic, Range, Negated Range, and Logistic Regression. Desktop GARP Dataset Manager was used to combine layers.

Two sets of species occurrence data (i.e., maximum and minimum) was used in the Desktop GARP. Fifty percent of the occurrence data was used for model building (i.e., training) in which the model randomly selected half of the occurrence data as training and reserved the other half for testing.

Evaluations of the forecasts were made by identifying which areas were predicted to match the environmental requirements of each species in multiple runs of the model building (Rivera et al. 2007). A total of 20 runs were conducted for each species, and the 20 outputs were then stacked in ArcGIS 9.1, using the grid calculator. Models were developed by binning these outputs by percent overlap and re-projected the multiple model runs over the region. This identified how well the series of models predicted occurrences outside the model input scope.

The GARP program calculates errors of commission and omission. Commission error evaluated the percentage of the predicted area that exceeded the recorded occurrence. Internal omission errors were applied to check the degree of failing in order to predict the known distribution of each species where they were predicted actually as absent. Thus, we evaluated how well each model predicts the occurrence data which were used in the construction of the model. The extrinsic omission represents the percentage of the testing data that are omitted from the prediction; that is, those occurrence data which are predicted as absent, but where presence is observed within the records. The GARP program also calculates a chi square statistic for each model to evaluate its observed success in predicting the distribution of test points, based on the model developed using the training data, against expected 
success under a random model.

\section{Results and discussion}

Our runs showed that the median commission error from the 20 model runs was $23.4 \%$ (Table 1). Internal omission errors were nil, suggesting that each model correctly predicted the occurrence data that were used in building that model. Median external omission error was $13.4 \%$. These relatively high rates for commission and external omission errors appear to be related to the small number of sampling sites $(n=24)$, which were randomly divided by half into two sets of data for training and for building the model. The results of our analyses showed that in four cases the $\mathrm{p}$-value was relatively high $(\mathrm{p}=$ $0.20-0.24)$, while the remainder were significant $(p<0.05)$, suggesting that model predicted occurrences much more accurately than random prediction.

Our GARP model captures the distribution of this species on the East Coast. It seems that $B$. perforatus has

Table 1. Value of model errors and statistical results for each run of the model

\begin{tabular}{crrrcr}
\hline Run & $\begin{array}{c}\text { Chi- } \\
\text { Square } \\
\text { value }\end{array}$ & $\boldsymbol{P}$-value & $\begin{array}{c}\text { Commission } \\
\text { error } \\
\mathbf{( \% )}\end{array}$ & $\begin{array}{c}\text { Internal } \\
\text { omission } \\
\text { error } \\
\mathbf{( \% )}\end{array}$ & $\begin{array}{c}\text { External } \\
\text { omission } \\
\text { error } \\
\mathbf{( \% )}\end{array}$ \\
\hline 1 & 11.5 & 0.00 & 16.0 & 0.0 & 33.3 \\
2 & 5.2 & 0.02 & 38.2 & 0.0 & 16.7 \\
3 & 1.5 & 0.23 & 15.5 & 0.0 & 66.7 \\
4 & 5.4 & 0.02 & 37.5 & 0.0 & 16.7 \\
5 & 4.1 & 0.04 & 29.0 & 0.0 & 33.3 \\
6 & 9.7 & 0.00 & 26.9 & 0.0 & 16.7 \\
7 & 1.5 & 0.22 & 58.5 & 0.0 & 16.7 \\
8 & 10.6 & 0.00 & 25.5 & 0.0 & 16.7 \\
9 & 13.4 & 0.00 & 14.3 & 0.0 & 33.3 \\
10 & 4.9 & 0.03 & 8.3 & 0.0 & 66.7 \\
11 & 3.5 & 0.06 & 31.3 & 0.0 & 33.3 \\
12 & 7.9 & 0.00 & 43.0 & 0.0 & 0.0 \\
13 & 1.6 & 0.21 & 41.3 & 0.0 & 33.3 \\
14 & 4.6 & 0.03 & 56.3 & 0.0 & 0.0 \\
15 & 4.5 & 0.03 & 17.2 & 0.0 & 50.0 \\
16 & 1.6 & 0.20 & 14.8 & 0.0 & 66.7 \\
17 & 12.4 & 0.00 & 9.0 & 0.0 & 50.0 \\
18 & 7.0 & 0.01 & 32.8 & 0.0 & 16.7 \\
19 & 12.6 & 0.00 & 22.6 & 0.0 & 16.7 \\
20 & 13.3 & 0.00 & 14.4 & 0.0 & 33.3 \\
\hline Median & 5.37 & - & 23.4 & 0.0 & 13.4 \\
\hline & & & & & \\
\hline
\end{tabular}

rapidly colonized the East coast of Korea following its introduction in the region. Based on the northern limit of its distribution in Sacheon Port $\left(37^{\circ} 50^{\prime} 00^{\prime \prime} \mathrm{N}, 128^{\circ} 52^{\prime} 36^{\prime \prime} \mathrm{E}\right)$ in 2008 and its first findings in ports at around $35^{\circ} \mathrm{N}$ in 2006 (see above), its movement is approximately equivalent to the movement of water with passive larvae of about $300 \mathrm{~km}$ to the north over a two year period, extending its northern distribution by $150 \mathrm{~km}$ a year (Fig. 2). As the species does have a planktonic life-stage, they are likely to spread intra-regionally by natural currents of the region, such as the Tsushima Warm Current.

A strong regional pattern emerged for the predicted region of the invasions of the marine species (Fig. 4). The success of the establishment of this invasive species is dependent primarily on the temperature of recipient waters (Herbert et al. 2003). Mean surface temperatures in summer around the English Channel, where a large number of the common barnacle were recently found, are $15-18^{\circ} \mathrm{C}$ and those in winter are $6-9^{\circ} \mathrm{C}$ (Hiscock et al., 2004). In the Western Mediterranean where this species is very abundant in the intertidal rocky shore, the annual average SST recorded between 1982 and 1990 was about $19^{\circ} \mathrm{C}$, with $25^{\circ} \mathrm{C}$ in summer and $15^{\circ} \mathrm{C}$ in winter. On the other hand, the mean August SST between 1970 and 2000 around

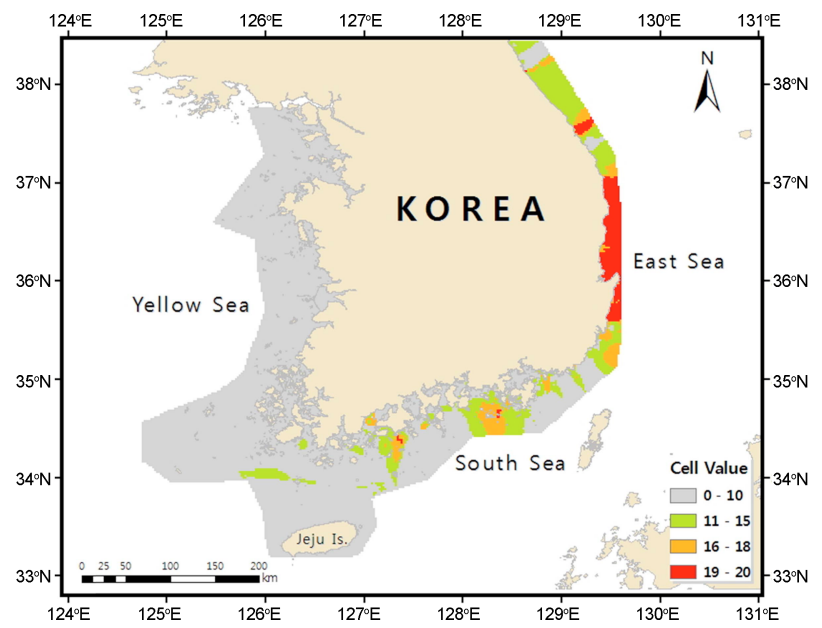

Fig. 4. Predicted distribution map of $B$. perforatus based on environmental information and species distribution data. The different colors represent varying degrees of likelihood for expansion of the species. Cell value represents the number of runs that predicted an environmental match, greater cell values indicate higher confidence in prediction. The red shading indicates the greatest confidence in predicted areas suitable for establishment, and confidence in the predictions declines as the cell value decreases 
Ulsan and Pohang Ports in Korea, where the population of B. perforatus is established, reaches $25^{\circ} \mathrm{C}$, while the mean February SST reaches $11^{\circ} \mathrm{C}$ (Japanese Meteorological Agency). Therefore, the temperature condition in the recipient waters in Korea is well within its distributional range, and this may imply the rapid colonization of this invasive species in Korean coasts after settlement.

On British coasts, this barnacle B. perforatus had a limited south-western distribution (Southward et al. 1998), but its distribution is expected to extend further north and east with a warming climate (Hiscock et al. 2004). Subsequently the range has extended eastwards to Hastings on the English side of the Channel and to Le Treport on the French side and it has extended its range eastward by about $100 \mathrm{~km}$ in the past $25 \mathrm{yr}$ (Herbert et al. 2003). This species is now established in places in the eastern English Channel which were formerly considered to be too cold for its year-round survival. This suggests that this species could spread further northwards along the east coast of Korea.

The results show that the southern coastal region is vulnerable to the establishment of the species if introduced (Fig. 4), but the West coast of Korea turns out to be a region of low probability for establishment. Water temperature is somewhat lower in the west coast than that observed in the other two coasts (Fig. 3). Average salinity appeared to be higher in the east coast, but chlorophyll a concentration is generally higher in the south and west coast, with regional hot spots, than in the east coast (Fig. 3 ). The concentration of suspended solids is notably greater on the west coast, with localized high concentrations around major tidal flats (e.g., Ganghwa Tidal Flat and Saemangeum Tidal Flat, Fig. 3). The survival, growth and fecundity of a transplanted barnacle population at the Squamish estuary, British Columbia, were studied for one year. The transplanted barnacles were found to show poor survival, fecundity and growth compared to a control population in West Vancouver. These were related to the prevailing stress conditions of low, fluctuating salinity and high turbidity at the estuary (Wu and Levings 1979). The west coast of Korea is certainly a place of elevated disturbance, as seen in the variable suspended solids concentration. The exact causes for low probability of invasion on the west coast should be further studied, with expanded sampling on the west and south coasts.

\section{Acknowledgements}

We thank Hyun-Hee Lee for her assistance with GIS analyses. This study was funded by National Research Foundation of Korea (PN65360 to K.H. Choi).

\section{References}

Chavanich S, Tan L, Vallejo B, Viyakam V (2010) Report on the current status of marine non-indigenous species in the Western Pacific Region. In: Intergovernmental Oceanographic Commission Sub-Commission for the Western Pacific (IOC/WESTPAC), Bangkok, Thailand, 9-16 Jul 2010, pp 61

De Rivera CE, Steves BP, Ruiz GM, Fofonoff P, Hines AH (2007) Northward spread of marine nonindigenous species along Western North America: Forecasting risk of colonization in alaskan waters using environmental Niche modeling. http://www.pwsrcac.org/docs/d0041100.pdf Accessed 25 Jan 2013

Herbert RJH, Hawkins SJ, Sheader M, Southward AJ (2003) Range extension and reproduction of the barnacle Balanus perforatus in the eastern English Channel. J Mar Biol Assoc UK 83:73-82

Herborg LM, Jerde CL, Lodge DM, Ruiz GM, MacIsaac HJ (2007) Predicting invasion risk using measures of introduction effort and environmental niche models. Ecol Appl 17(3):663-674

Hiscock K, Southward A, Tittley I, Hawkins S (2004) Effects of changing temperature on benthic marine life in Britain and Ireland. Aquat Conserv 14(4):333-362

Iguchi K, Matsuura K, McNyset KM, Peterson AT, ScachettiPereira R, Powers KA, Vieglais DA, Wiley EO, Yodo T (2004) Predicting invasions of North American basses in Japan using native range data and a genetic algorithm. Trans Am Fish Soc 133(4):845-854

Kim I, Hong J (2010) Introduction of the European Common Barnacle Balanus perforatus Brugiére (Crustacea, Cirripedia) into Korean Waters. In: 17th International Conference on Aquatic Invasive Species, San Diego, USA, 29 Aug-2 Sep 2010, pp 24

Loo SE, Nally RM, Lake PS (2007) Forecasting new zealand mudsnail invasion range: model comparisons using native and invaded ranges. Ecol Appl 17(1):181189

Ohtsuka S, Horiguchi T, Lopes R, Choi K, Iwasaki K (2004) Plankton introduction via ship ballast water: A review. Bull Plankton Soc Jpn 51(2):101-118

RSS WU, Levings CD (1979) Energy flow and population dynamics of the barnacle (Balanus glandula). Mar Biol 54:83-89

Southward AJ, Burton RS, Coles SL, Dando PR, De Felice 
R, Hoover J, Parnell PE, Yamaguchi T, Newman WA (1998) Invasion of Hawaiian shores by an Atlantic barnacle. Mar Ecol Prog Ser 165:119-126

Stockwell DRB, Peters DG (1999) The GARP modelling system: Problems and solutions to automated spatial prediction. Int J Geogr Inf Sci 13(2):143-158

Wu RSS, Levings CD (1979) Energy flow and population dynamics of the barnacle Balanus glandula. Mar Biol 54(1):83-89

Received Sep. 3, 2012

Revised Oct. 27, 2012

Accepted Nov. 12, 2012 